\title{
GAMBARAN KEJADIAN INFEKSI LUKA OPERASI (ILO) PASCA BEDAH ABDOMEN DI RSUD ABDUL WAHAB SJAHRANIE SAMARINDA
}

\author{
Sepriani Indriati Azis ${ }^{1}$, P.M.T. Mangalindung Ompusunggu ${ }^{2}$, Hadi Irawiraman ${ }^{3}$ \\ ${ }^{1}$ Program Studi Pendidikan Dokter, Fakultas Kedokteran Universitas Mulawarman \\ ${ }^{2}$ Laboratorium Ilmu Bedah, Fakultas Kedokteran Universitas Mulawarman \\ ${ }^{3}$ Laboratorium Patologi Anatomi, Fakultas Kedokteran Universitas Mulawarman \\ Email:Sepriani.indriati126@gmail.com,mangalindung@gmail.com
}
Dikirim : $\quad 23$ Oktober 2019
Diterima : 30 Januari 2020
Diterbitkan : 20 Maret 2020

ABSTRACT

Surgical site infection (SSI) is an infection at the part of the body that was exposed by a surgeon during an operation. SSI is one of the most common and most preventable nosocomial infection among other nosocomial infections, but the incidence of surgical site infections especially in abdominal surgery still shows a significant burden. Risk factors of surgical site infections include old age, type of surgical wound, comorbidities, inadequate prophylactic antibiotics, nutritional statuses, and long duration of surgery. This study aimed to explain an overview of the incidence of postoperative abdominal wound infection in Abdul Wahab Sjahranie General Hospital, Samarinda. This research method was a laboratory descriptive study. The research data was taken from surgical wound swabs and medical record data of 40 post-abdominal surgery patients who made the bandage changes for the first time and met the inclusion and exclusion criteria. The results showed 30 patients $(75 \%)$ had surgical site infections. The highest percentage of infected patients aged over 40 years, i.e. in 15 people (37.5\%). Most of the infected patients had clean contaminated wounds, i.e. in 23 patients (57.5\%). The majority of infected patients did not have concomitant diseases, i.e. 27 people (67.5\%). Gram-positive bacteria, specifically Staphylococcus epidermidis was the most infectious bacteria identified in 10 patients (33.3\%). All infected patients, i.e. 30 patients (75\%) received prophylactic antibiotics. The highest frequencies of infected patients had normal nutritional status, i.e.17 patients(42.5\%), and the incidence of infection was more common in patients with duration $<120$ minutes, i.e. 20 patients $(50 \%)$

Keywords: Surgical site infection, SSI, Abdominal Surgery 


\section{PENDAHULUAN}

Angka kejadian infeksi, salah satunya infeksi nosokomial masih terbilang tinggi baik di Negara maju maupun Negara berkembang('Global Guidelines for the Prevention of Surgical Site Infection', 2016). Organisme nosokomial dapat menginfeksi luka pasca pembedahan kemudian bermanifestasi sebagai infeksi luka operasi (ILO) atau surgical site infections (SSI)(Collaborative, 2017). ILO adalah salah satu infeksi nosokomial yang paling umum. Infeksi luka operasi merupakan infeksi nosokomial yang paling dapat dicegah diantara infeksi nosokomial lainnya, namun infeksi luka operasi tetap berpotensi terjadi pada semua tipe operasi sehingga kejadian ILO sendiri masih menunjukkan beban yang signifikan kepada pasien maupun tempat pelayanan kesehatan('Global Guidelines for the Prevention of Surgical Site Infection', 2016). Infeksi luka operasi (ILO) lebih sering terjadi pasca pembedahan di daerah abdomen dibandingkan dengan pasca pembedahan di daerah lainnya(Beliman \& Dunn, 2015). ILO terjadi pada 25\% sampai $40 \%$ pasien post laparotomi serta menyumbang sepertiga dari kematian pasca operasi dan 8\% kematian akibat infeksi nosokomial(Collaborative, 2017). Tingginya kejadian infeksi luka operasi tersebut dipengaruhi oleh berbagai faktor risiko yang mempengaruhi proses penyembuhan luka operasi(Agrawal \& Singh, 2014).

Infeksi luka operasi memiliki faktor risiko yang tidak dapat diubah seperti faktor usia, karena semakin tua umur pasien maka akan semakin rendah cell mediated immunity pasien tersebut, sehingga pasien yang berusia tua imunitasnya akan menurun dan lebih rentan terkena infeksi(Kurnia, Tripriadi and Andrini, 2013). Faktor lain yaitu Obesitas, dapat menghambat penyembuhan luka operasi karena pembuluh darah yang seharunya membawa mediator peradangan dihalangi oleh tebalnya lemak subkutan(Janugade et al., 2016). Faktor sterilitas juga berperan penting terhadap kejadian infeksi luka operasi, karena sumber infeksi luka operasi dapat berasal dari ruangan serta peralatan yang digunakan selama operasi(Roy, 2014). Hipotermia, hipoksia dan nekrosis jaringan juga ikut mempengaruhi penyembuhan luka pasca operasi(Beliman \& Dunn, 2015). Faktor lain, yaitu durasi operasi dan jenis luka operasi ikut mempengaruhi kejadian infeksi luka operasi, karena semakin lama paparan antara dunia luar dengan daerah pembedahan serta semakin kotor luka operasi, maka akan semakin tinggi kemungkinan infeksi pada luka('Global Guidelines for the Prevention of Surgical Site Infection', 2016). Pada luka yang telah terinfeksi, patogen penyebab infeksi yang didapat dari luka operasi bersih dapat berbeda dari patogen yang didapat dari luka operasi kotor(Spagnolo et al., 2013). Identifikasi patogen penginfeksi luka operasi perlu dilakukan untuk mendapatkan terapi 
yang tepat('Global Guidelines for the Prevention of Surgical Site Infection', 2016). Penggunaan antibiotik yang tepat dapat mengurangi risiko resistensi bagi pasien sehingga dapat mengurangi morbiditas dan mortalitas pasien(Behnke et al., 2013). Identifikasi patogen penginfeksi dapat menjadi gambaran persebaran patogen di tempat pelayanan kesehatan sehingga dapat mempermudah upaya pengendalian kejadian infeksi di tempat pelayanan kesehatan tersebut(Roy, 2014).

Standarisasi praktik aseptik di kamar operasi telah diterapkan secara besarbesaran sejak abad ke 20, namun kejadian infeksi luka operasi pada prosedur operasi yang melibatkan struktur anatomi dengan flora endogen yang padat seperti kolon dan rektum tetap saja tinggi(Collaborative, 2017). Rumah sakit maupun tenaga kesehatan telah berusaha untuk mengupayakan seminimal mungkin angka kejadian infeksi luka pasca operasi, namun kenyataannya angka kejadian infeksi luka operasi terutama infeksi luka pasca bedah di regio abdomen masih terhitung tinggi, oleh karena itu peneliti tertarik untuk mengetahui gambaran kejadian infeksi luka operasi pasca bedah abdomen di RSUD Abdul Wahab Sjahranie Samarinda.

\section{METODE PENELITIAN}

Jenis penelitian ini adalah penelitian dengan studi deskriptif laboratorik untuk mengetahui kejadian infeksi luka operasi pasca bedah abdomen, meliputi angka kejadian, usia, jenis luka operasi, penyakit penyerta, gambaran bakteri pada luka, pemberian antibiotik profilaksis, durasi operasi dan status nutrisi pasien pasca bedah abdomen di RSUD Abdul Wahab Sjahranie Samarinda.

Sampel dalam penelitian ini diambil dengan menggunakan metode purposive sampling. Sampel diambil sesuai dengan kriteria inklusi dan ekslusi yang telah ditentukan. Pada penelitian ini, didapatkan 40 orang pasien.

Kriteria inklusi:

1. Pasien pasca bedah abdomen dari Instalasi Bedah Sentral (IBS) RSUD Abdul Wahab Sjahranie Samarinda yang menjalani rawat inap dan melakukan pergantian balutan luka pertama.

2. Bersedia menjadi sampel penelitian

Kriteria ekslusi:

1. Pasien pasca bedah abdomen dari Instalasi Bedah Sentral (IBS) RSUD Abdul Wahab Sjahranie Samarinda yang telah menjalani pergantian balutan lebih dari satu kali. 
2. Tidak bersedia untuk menjadi sampel penelitian.

3. Rekam medik pasien tidak lengkap.

Data yang digunakan dalam penelitian ini merupakan data primer yaitu data yang didapatkan langsung dari pasien dengan cara melakukan swab luka operasi pada pergantian balutan pertama yang kemudian dikirim ke UPTD Laboratorium Kesehatan Daerah Provinsi Kalimantan Timur untuk dikultur. Pada penelitian ini juga digunakan data sekunder yaitu data rekam medis pasien.

Analisis data dalam penelitian ini merupakan analisis univariat untuk mendeskripsikan distribusi frekuensi dan presentasi dari tiap variabel nya.Pengolahan data dilakukan dengan 3 tahapan, yaitu input data, edit data dan tabulasidata menggunakan Microsoft Excel 2007 dan IBM SPSS Statistic 25. Penyajian datadilakukan dalam bentuk narasi dan tabel.

\section{HASIL DAN PEMBAHASAN}

Penelitian ini dilakukan untuk mengetahui gambaran kejadian infeksi luka operasi pasca bedah abdomen di RSUD Abdul Wahab Sjahranie Samarinda dan mendapatkan izin untuk dilakukan di tiga ruang rawat inap, yaitu ruang Mawar, Aster dan Cempaka.

Tabel 1. Gambaran Distribusi Frekuensi Ruang Rawat Inap Tempat Pengambilan Sampel

\begin{tabular}{ccc}
\hline $\begin{array}{c}\text { Ruang } \\
\text { rawat inap }\end{array}$ & Frekuensi & $\begin{array}{c}\text { Persentase } \\
(\%)\end{array}$ \\
\hline Mawar & 26 & 65 \\
Aster & 3 & 7,5 \\
Cempaka & 11 & 27,5 \\
\hline
\end{tabular}

Pada peneltian ini, frekuensi tempat pengambilan sampel terbanyak ada pada ruang rawat inap kebidanan, yaitu ruang Mawar.

Tabel 2 Gambaran Distribusi Frekuensi Umum Seluruh Sampel dari Ruang Rawat Inap Mawar, Aster dan Cempaka

\begin{tabular}{lcc}
\hline & Frekuensi & $\begin{array}{c}\text { Persentase } \\
(\%)\end{array}$ \\
\hline Infeksi Luka & & \\
Operasi & 30 & 75 \\
Ya & 10 & 25 \\
$\quad$ Tidak & 10 & \\
\hline Usia & 7 & 25 \\
$15-30$ tahun & & 17,5
\end{tabular}




\begin{tabular}{lcc}
\hline $41-59$ tahun & 19 & 47,5 \\
$\geq 60$ tahun & 4 & 10 \\
\hline Jenis Luka & & \\
Operasi & & \\
Bersih & 11 & 27,5 \\
Bersih & 29 & 72,5 \\
Terkontaminasi & & - \\
Terkontaminasi & - & - \\
$\quad$ Kotor & - & \\
\hline Penyakit & & \\
penyerta & & 90 \\
Tidak ada & 36 & 7,5 \\
Diabetes & 3 & 2,5 \\
Mellitus & 1 & \\
Anemia & & \\
\hline Pemberian & & \\
antiobiotik & & - \\
profilaksis & & \\
Ya & 40 & - \\
Tidak & - & 52,5 \\
\hline Status Gizi & & 35 \\
Kurang & - & 12,5 \\
Normal & 21 & \\
Berlebih & 14 & 5 \\
Obesitas & 5 & \\
\hline Durasi & &
\end{tabular}

\section{Durasi \\ Operasi}

$<120$ menit $\quad 24 \quad 60$

$\geq 120$ menit $\quad 16 \quad 40$

Pada penelitian ini, mayoritas pasien, yaitu 30 orang (75\%) pasien positif mendapatkan infeksi luka operasi yang teridentifikasi pada pergantian balutan pertama. Pasien dengan rentang usia 41 - 59 tahun merupakan rentang usia terbanyak yang menjadi sampel penelitian, yaitu ditemukan pada 19 orang (47,5\%) pasien. Frekuensi jenis luka operasi bersih terkontaminasi merupakan jenis luka operasi yang paling banyak ditemukan, yaitu 29 orang $(72,5 \%)$ pasien. Sebagian besar pasien, yaitu36 orang (90\%) pasien tidak memiliki penyakit penyerta yang dapat mempengaruhi penyembuhan luka pasca operasi. Seluruh pasien, yaitu 40 orang (100\%) pasien pada penelitian ini menerima antibiotik profilaksis. Pada 21 orang $(52,5 \%)$ pasien memiliki status gizi normal. Kebanyakan pasien memiliki durasi operasi <120 menit, yaitu 24 orang $(60 \%)$ pasien.

Tabel 3 Gambaran Distribusi Frekuensi Pasien dengan Infeksi Luka Operasi

\begin{tabular}{ccc}
\hline & Frekuensi & $\begin{array}{c}\text { Persentase } \\
(\%)\end{array}$ \\
\hline Usia & & \\
$15-30$ tahun & $6 / 40$ & 15 \\
$31-40$ tahun & $7 / 40$ & 17,5 \\
\hline
\end{tabular}




\begin{tabular}{ccc}
\hline $41-59$ tahun & $15 / 40$ & 37,5 \\
$\geq 60$ tahun & $2 / 40$ & 5 \\
\hline $\begin{array}{c}\text { Jenis Luka } \\
\text { Operasi }\end{array}$ & & \\
Bersih & $7 / 40$ & 17,5 \\
Bersih & $23 / 40$ & 57,5 \\
Terkontaminasi & - & - \\
Terkontaminasi & - & - \\
Kotor & - & \\
\hline Penyakit & & \\
penyerta & & 67,5 \\
Tidak ada & $27 / 40$ & 5 \\
Diabetes & $2 / 40$ & \\
Mellitus & $1 / 40$ & 2,5 \\
Anemia & & \\
\hline Pemberian & & \\
antiobiotik & & \\
profilaksis & & \\
Ya & $30 / 40$ & - \\
Tidak & - & - \\
\hline Status Gizi & & \\
Kurang & - & \\
Normal & $17 / 40$ & 42,5 \\
Berlebih & $9 / 40$ & 22,5 \\
Obesitas & $4 / 40$ & 10 \\
\hline Durasi & & \\
Operasi & & 50 \\
$<120$ menit & $20 / 40$ & 25 \\
$\geq 120$ menit & $10 / 40$ & \\
\hline & & \\
\hline
\end{tabular}

\section{Gambaran Kejadian Infeksi Luka Operasi Pasca Bedah Abdomen Di RSUD Abdul Wahab Sjahranie Samarinda}

Hasil penelitian ini menunjukkan bahwa $75 \%$ sampel luka operasi pasien pasca bedah abdomen yang diambil saat pergantian balutan pertama di RSUD Abdul Wahab Sjharanie, Samarinda, positif teridentifikasi bakteri.

Hasil penelitian ini tidak sejalan dengan penelitian Alkaaki et al., (2019)dan Emil et al., (2015)dimana pada penelitian tersebut kejadian infeksi luka operasi pada bedah abdomen yang ditandai dengan perlambatan penutupan luka lebih kecil dibandingkan dengan kejadian tidak terinfeksi.

Angka yang cukup tinggi ini bisa saja terjadi karena peneliti hanya menggunakan satu kriteria diagnosis untuk mendiagnosis infeksi luka operasi. Infeksi luka operasi sejatinya dapat didiagnosis apabila terjadi dalam waktu 30 hari pasca operasi dengan hari pertama operasi merupakan hari ke-1. Untuk mendiagnosis infeksi luka operasi, diperlukan minimal satu syarat berikut, yaitu 1) Infeksi luka operasi didiagnosis langsung 
oleh dokter bedah atau dokter yang merawat; 2) Luka operasi mengeluarkan sekret purulen dengan atau tanpa konfirmasi laboratorium; 3) Hasil kultur cairan maupun jaringan pada luka operasi positif teridentifikasi mikroorganisme; 4) Luka tersebut terbuka kemudian luka tersebut didiagnosis oleh ahli bedah bahwa telah terinfeksi dan dari salah satu kriteria diatas diikuti oleh salah satu tanda peradangan seperti kemerahan, pembengkakan, nyeri dan panas(CDC, 2019). Tanda peradangan sendiri, berupa kemerahan saja dapat muncul sejak hari pertama luka operasi (Beliman \& Dunn, 2015).

Pada penelitian ini, peneliti menggunakan kriteria nomor 3 untuk mendiagnosis kejadian infeksi dan tidak melakukan evaluasi pada manifestasi klinis lanjutan seperti perlambatan penyembuhan luka atau pengeluaran pus. Angka kejadian infeksi yang tinggi ini belum tentu menyebabkan manifestasi klinis berupa gangguan penutupan luka karena bisa saja bakteri yang di dapatkan merupakan bakteri komensal pada kulit. Pada penelitian ini juga tidak dilakukan penelitian jumlah bakteri yang teridentifikasi pada luka operasi, karena sejatinya, bahkan bakteri komensal saja dalam jumlah tertentu dan pada pasien dengan sistem imun lemah, bisa menyebabkan infeksi luka operasi(Ziebuhr et al., 2006). Investasi bakteri sejumlah $\geq 10^{6} c f u$ (colony forming unit)/ml terbukti dapat menyebabkan infeksi pasca bedah, akan tetapi investasi bakteri tidak bekerja sendirian dalam menyebabkan infeksi luka pasca operasi(Kallstrom, 2014). Faktor risiko lain, seperti pasien dengan usia tua, yaitu lebih dari 60 tahun, jenis luka operasi bersih terkontaminasi, terkontaminasi dan kotor, status gizi yang tidak baik seperti obesitas dan malnutrisi, penyakit penyerta seperti diabetes, pemberian antibiotik profilaksis yang tidak adekuat, serta durasi operasi yang lama, yaitu lebih dari 120 menit, terbukti turut memiliki andil besar dalam menyebabkan perlambatan penyembuhan luka pasca operasi(Beliman \& Dunn, 2015).

Gambaran Usia Pasien Infeksi Luka Operasi Pasca Bedah Abdomen Di RSUD Abdul Wahab Sjahranie Samarinda

Pada penelitian ini terjadi peningkatan kejadian infeksi luka operasi pada usia diatas 40 tahun. Hasil penelitian ini sejalan dengan penelitian Kurnia, Tripriadi and Andrini, (2013) di RSUD Arifin Achmad, Riau dan Faridah, Andayani dan Inayati, (2012)di Rumah Sakit PKU Muhammadiyah Yogyakarta dimana pada penelitian tersebut frekuensi usia infeksi luka operasi lebih banyak ditemukan pada pasien dengan usia diatas 40 tahun. 
Hal ini dapat dikarenakan peningkatan usia mempengaruhi perubahan struktural dan fungsional tubuh yang menyebabkan tubuh lebih rentan terhadap infeksi. Peningkatan usia dapat meningkatkan kejadian infeksi luka operasi dikarenakan peningkatan jumlah penyakit yang mulai muncul seiring peningkatan usia dan penurunan ketahanan imunologis tubuh(Kurnia, Tripriadi and Andrini, 2013). Hal ini dikarenakan, pada umumnya semakin tua usia manusia, maka akan berdampak pada perubahan maturasi dan diferensisasi sel $\mathrm{T}$ dan sel B yang di produksi di sumsum tulang belakang dan di jaringan limfosit. Perubahan maturasi dan diferensiasi itu lah yang menyebabkan manusia berusia tua tidak memberikan respon imun sekuat manusia muda(Montecino-rodriguez et al., 2013).

\section{Gambaran Jenis Luka Operasi Pasien Infeksi Luka Operasi Pasca Bedah Abdomen Di RSUD Abdul Wahab Sjahranie Samarinda}

Pada penelitian ini, sebagian besar pasien infeksi luka operasi memiliki jenis luka operasi bersih terkontaminasi. Penelitian ini sejalan dengan penelitian Emil et al., (2015) yang dilaksanakan di Israel. Pada penelitian tersebut kejadian infeksi luka operasi pada jenis luka operasi bersih terkontaminasi lebih tinggi dari pada kejadian tidak terinfeksi, dimana pada penelitian tersebut didapatkan kejadian infeksi $32,3 \%$ dan tidak terinfeksi $27 \%$.

Hal ini dapat dikarenakan jenis luka operasi bersih terkontaminasi memiliki kemungkinan besar terpapar oleh flora endogen tubuh dimana flora endogen telah terbukti bertanggung jawab atas sebagian besar kasus infeksi luka operasi pada bedah abdomen(Janugade et al., 2016). Pada penelitian ini, lebih banyak didapatkan pasien kebidanan. Pada operasi bersih terkontaminasi yang berhubungan dengan organ genitalia, terdapat kontak antara bidang operasi dengan flora endogen pada vagina, traktus gastrointestinal dan kulit yang di insisi saat operasi. Kombinasi ketiga faktor tersebut, menyebabkan risiko infeksi luka pada daerah operasi pasca bedah kebidanan cukup tinggi(Steiner and Strand, 2017).

\section{Gambaran Penyakit Penyerta Pasien Infeksi Luka Operasi Pasca Bedah Abdomen Di RSUD Abdul Wahab Sjahranie Samarinda}

Pada penelitian ini sebagian besar pasien yang mengalami infeksi luka operasi pada pergantian balutan pertama, tidak memiliki penyakit penyerta. Hasil penelitian tidak sejalan dengan penelitian Faridah, Andayani and Inayati, (2012). Hal ini dapat dijelaskan 
karena meskipun sebagian besar pasien tidak memiliki penyakit penyerta, sebagian besar pasien pada penelitian ini mendapatkan jenis luka operasi bersih terkontaminasi. Jenis luka operasi bersih terkontaminasi merupakan jenis luka operasi yang berpotensi tinggi mendapatkan infeksi luka operasi(Beliman \& Dunn, 2015). Begitu pula dengan faktor lain yang kemungkinan besar dapat berpengaruh terhadap invasi bakteri pada luka operasi. Disisi lain, 2 dari 3 pasien Diabetes Mellitus pada penelitian ini mendapatkan infeksi luka operasi. Hasil ini sejalan dengan penelitian Al-Niaimi et al., (2015).

Penyembuhan luka pasca operasi pasien diabetes dapat terganggu. Hal ini dapat dijelaskan karena proses penyembuhan luka merupakan suatu proses tumpang tindih yang terdiri dari fase inflamasi, proliferasi dan remodelling. Pada penderita Diabetes Mellitus, fase penyembuhan luka tersebut menjadi terganggu(Kunkemoeller and Kyriakides, 2017).

Fase inflamasi pada diabetes memanjang namun tidak efektif. Pada diabetes, terjadi inflamasi kronis yang ditandai dengan peningkatan mediator proinflamasi seperti Macrophage Cemoattractant Protein-1 (MCP-1), Tumor Necrosis Factor (TNF) dan Interleukin-6 (IL-6). Mediator-mediator ini dapat menyebabkan inflamasi kronis. Saat pasien diabetes terluka, seperti luka pasca operasi, neutrofil dan makrofag datang dalam waktu yang lebih lambat dibandingkan dengan orang sehat. Setelah tiba, mereka akan bertahan lebih lama dari pada waktu yang seharusnya. Neutrofil dan Makrofag yang bertahan lama ini malah membuat inflamasi kronis dan membuat luka semakin parah(Kunkemoeller and Kyriakides, 2017). Proses ini dapat dikarenakan pada pasien diabetes terjadi defek pada sistem saraf otonom, endotel dan metabolisme lokal jaringan yang berdampak pada defek mikrosirkulasi tubuh. Mikrosirkulasi pada manusia diatur oleh regulasi sentral dan lokal. Regulasi sentral disampaikan melalui saraf simpatis dan parasimpatis yang sampai kepada otot polos. Sedangkan regulasi lokal diatur oleh substansi yang dihasilkan oleh endotel dan kebutuhan metabolisme jaringan (Dokken, 2008).

Pada pasien normal, otot polos endotel menerima regulasi sentral untuk menghasilkan vasodilator Nitrit Oksida (NO). NO dibutuhkan untuk melebarkan pembuluh darah agar darah bisa menyesuaikan kebutuhan jaringan untuk mengalirkan kebutuhan metabolisme. Pada pasien diabetes terjadi Diabetic Autonomic Neurophaty (DAN). DAN merupakan salah satu faktor yang mempengaruhi fleksibilitas dari pembuluh darah. Disregulasi fleksibilitas pembuluh darah yang disebabkan oleh DAN, menyebabkan penurunan dari sekresi Nitrit Oksida(Kunkemoeller and Kyriakides, 2017). 
Pada penelitian ini hanya didapatkan 1 pasien Anemia dan pasien tersebut mendapatkan infeksi luka operasi yang teridentifikasi pada pergantian balutan pertama. Hal ini dapat terjadi karena pada pasien Anemia terjadi penurunan oksigenasi jaringan akibat kekurangan eritrosit yang dapat mengangkut oksigen. Oksigen diperlukan sebagai bahan pembentuk energi sel termasuk sel-sel jaringan yang cedera. Pasien yang mengalami anemia sebelum operasi biasanya mendapatkan trasnfusi darah, pasien yang mendapatkan transfusi akan mengalami penekanan imunitas tubuh, sehingga mediator inflamasi yang penting untuk proses penyembuhan luka seperti neutrofil akan berkurang(Hu et al., 2018).

\section{Gambaran Pemberian Antibiotik Profilaksis Pasien Infeksi Luka Operasi Pasca Bedah Abdomen Di RSUD Abdul Wahab Sjahranie Samarinda}

Seluruh pasien pada penelitian ini mendapatkan antibiotik profilaksis, dimana terdapat 30 pasien $(75 \%)$ diantaranya yang mendapatkan infeksi luka operasi yang teridentifikasi pada pergantian balutan pertama.

Hasil penelitian ini tidak sejalan dengan penelitian Kiran, Murray, Chiuzan, Estrada, \& Forde, (2015) dan hasil penelitian Blanchard, (2015)yang membandingkan kejadian infeksi luka operasi pada pasien yang diberikan antibiotik selama operasi dengan yang tidak diberikan antibiotik. Penelitian tersebut membuktikan bahwa pemberian antibiotik profilaksis selama operasi memberikan hasil yang signifikan untuk mencegah infeksi luka operasi.

Hal ini bisa saja terjadi karena pemberian antibiotik profilaksis yang tidak adekuat saja, belum tentu menjadi penyebab tunggal infeksi luka operasi. Tetap diperlukan kombinasi dari faktor lainnya untuk menyebabkan infeksi luka operasi.Pemberian antibiotik profilaksis umunya digunakan untuk mencegah infeksi pasca bedah yang disebabkan oleh bakteri nosokomial tersebut(Xia, Gao \& Tang, 2016).Ceftriaxone merupakan obat golongan sefalosporin generasi ketiga yang banyak digunakan secara luas di seluruh dunia. Ceftriaxone merupakan antibiotik profilaksis yang juga digunakan di RSUD Abdul Wahab Sjahranie Samarinda dandianggap manjur secara klinis karena memiliki farmakokinetik yang menguntungkan serta frekuensi efek samping yang rendah. Ceftriaxone umumnya kurang sensitif terhadap bakteri gram positif seperti Streptococcus dan Stafilococcus, namun Ceftriaxone sensitif terhadap kebanyakan bakteri gram negatif seperti Escherichia coli(Liu et al., 2014). Bakteri gram negatif merupakan penyebab tersering pada infeksi luka bedah abdomen (Beliman \& Dunn, 
2015). Pada penelitian ini, tidak banyak ditemukan bakteri gram negatif. Hal ini mungkin saja karena penggunaan antibiotik profilaksis di RSUD Abdul Wahab Sjahranie sudah tepat untuk mengeradiksi bakteri gram negatif namun kurang efektif untuk melawan bakteri gram positif.

\section{Gambaran Status Gizi Pasien Infeksi Luka Operasi Pasca Bedah Abdomen Di RSUD Abdul Wahab Sjahranie Samarinda}

Data penelitian pada tabel 3 menunjukkan bahwa sebagian besar pasien terinfeksi memiliki berat badan normal. Hasil penelitian ini berbeda dengan Janugade et al., (2016) dan Dobner \& Kaser, (2018). Hal ini bisa saja terjadi karena pada saat pengambilan sampel, peneliti banyak mendapatkan pasien dengan jenis luka operasi bersih terkontaminasi, pada jenis luka operasi tersebut, luka operasi pasien lebih rentan terkena infeksi luka operasi.

Pada penelitian ini, didapatkan pasien obesitas sebanyak 5 pasien $(12,5 \%)$ dimana 4 pasien (10\%) diantaranya terinfeksi dan hanya 1 pasien (2,5\%) tidak terinfeksi. Pada penelitian ini juga didapatkan pasien berat badan berlebih sebanyak 14 pasien (35\%) dengan 9 pasien $(22,5 \%)$ diantaranya terinfeksi. Hasil ini sejalan dengan penelitian Thelwall et al., (2015) dan Winfield et al., (2016). Pasien dengan berat badan berlebih dan obesitas memiliki oksigenasi lemak subkutan yang lebih rendah dibandingkan pasien dengan berat normal. Penyembuhan jaringan memiliki kebutuhan metabolik yang tinggi(Thelwall et al., 2015). Sel - sel imunitas tubuh juga memerlukan kadar oksigen yang tinggi untuk membuat energi yang digunakan untuk melawan patogen. Insufisensi oksigen yang terjadi ini menyebabkan perlambatan pada proses penyembuhan luka. Tingginya kadar lemak subkutan juga menyebabkan pemberian antibiotik profilaksis pada pasien obesitas memerlukan dosis yang lebih besar agar mencapai konsentrasi obat plasma yang sama dengan pasien dengan berat normal(Winfield et al., 2016).

\section{Gambaran Durasi Operasi Pasien Infeksi Luka Operasi Pasca Bedah Abdomen Di RSUD Abdul Wahab Sjahranie Samarinda}

Pada penelitian ini kebanyakan pasien infeksi luka operasi memiliki durasi operasi <120 menit. Hasil ini berbeda dengan penelitian Haryanti et al., (2016). Perbedaan ini dapat dikarenakan pada penelitian ini frekuensi infeksi luka operasi pada pasien dengan durasi <120 menit didominasi oleh jenis luka operasi bersih terkontaminasi. Hal ini mendukung terjadinya peningkatan kejadian infeksi karena jenis 
luka operasi bersih terkontaminasi lebih berpotensi terapar flora endogen tubuh dibandingkan dengan jenis luka operasi bersih(Beliman \& Dunn, 2015).

Durasi operasi $\geq 120$ menit merupakan faktor risiko dari luka operasi. Durasi operasi yang lama tersebut akan meningkatkan paparan mikroorganisme di kamar operasi dengan luka operasi. Durasi yang panjang tersebut juga dapat menurunkan efektivitas kerja dari antibiotik profilaksis(Emil et al., 2015). Durasi operasi yang lama dapat menyebabkan penurunan suhu tubuh atau bahkan hipotermia akibat kamar operasi yang dingin. Pada saat terjadi penurunan suhu tubuh, pembuluh darah di perifer tubuh akan melakukan vasokonstriksi untuk menyimpan panas tubuh. Vasokonstriksi pembuluh darah di daerah perifer tubuh yaitu kulit, dapat menyebabkan jaringan sekitar kulit kekurangan oksigen. Insufisiensi oksigen dapat menyebabkan hipoksia jaringan. Semakin lama durasi operasi, semakin besar derajat hipoksia jaringan perifer tubuh yang dapat terjadi. Hal ini dapat menyebabkan bakteri anaerob yang terdapat di lingkungan sekitar kamar operasi dapar menginvasi dan tumbuh subur di daerah luka operasi(Beliman \& Dunn, 2015).

\section{Gambaran Jenis Bakteri Pada Luka Operasi Pasien Pasca Bedah Abdomen Di RSUD Abdul Wahab Sjahranie Samarinda}

Tabel 4 Gambaran Jenis Bakteri Pada Luka Operasi Pasien $(\mathrm{n}=30)$

\begin{tabular}{ccc}
\hline Jenis Bakteri & Frekuensi & Persentase $(\%)$ \\
\hline Acinetobacter baumanii & 2 & 6,7 \\
Escherichia coli & 3 & 10 \\
Klebsiella ozaenae & 1 & 3,3 \\
Klebsiella pneumonia & 3 & 10 \\
Pseudomonas aeruginosa & 1 & 3,3 \\
Pantoea sp & 1 & 3,3 \\
Staphylococcus epidermidis & 10 & 33,3 \\
Staphylococcus aureus & 1 & 3,3 \\
Staphylococcus haemolyticus & 1 & 3,3 \\
Staphylococcus hominis & 1 & 3,3 \\
Staphylococcus xylosus & 1 & 3,3 \\
Serratia odorifera & 1 & 3,3 \\
Staphylococcus sp & 1 & 3,3 \\
Streptococus sp & 2 & 6,7 \\
Bakteri & & \\
campuranStreptococcus sp & 1 & 3,3 \\
dan Staphylococcus & & \\
epidermidis & & \\
\hline
\end{tabular}

Sebagian besar pasien yang terinfeksi, yaitu 60\% pasien, terinfeksi bakteri gram positif. Pada pasien yang terinfeksi, 33,3\% diantaranya mendapatkan infeksi bakteri 
Staphylococcus epidermidis. Hasil penelitian ini sejalan dengan penelitian yang dilakukan olehWarganegara, Apriliana \& Ardiansyah, (2012) di RSUD Dr. H. Abdul Moeloek, Bandar Lampung. Pada hasil penelitian tersebut, Staphylococcus epidermidis merupakan penginfeksi utama pada luka operasi.

Staphylococcus epidermidis merupakan bakteri komensal yang memang berada di epitel kulit manusia. Berbeda dengan kawan nya, yaitu Staphylococcus aureus yang berkoloni di hidung, Staphylococcus epidermidis bersifat lebih tidak invasif. Staphylococcus epidermidis diduga memiliki fungsi probiotik untuk mencegah kolonisasi dari bakteri patogen yang memiliki toksin yang kuat seperti Staphylococcus aureus atau mikroorganisme patogen lainnya(Otto, 2009). Fungsi ini menyebabkan Staphylococcus epidermidis akan bermultiplikasi sebagai bentuk perlawanan terhadap bakteri patogen. Bakteri patogen tersebut kalah secara jumlah, sehingga Staphylococcus epidermidis masih bisa mempertahankan rumah nya(Ziebuhr et al., 2006).

Staphylococcus epidermidis umumnya tidak berbahaya, namun bakteri ini merupakan bakteri nosokomial yang sering ditemukan selama 20 tahun terakhir. Staphylococcus epidermidis dapat berubah menjadi berbahaya karena faktor eksitrinsik yang menyebabkan gen bakteri ini berubah atau bisa jadi karena imunitas pasien yang sangat lemah. Bakteri nosokomial dapat ditularkan baik oleh manusia maupun oleh instrumen operasi(Cogen, Nizet and Gallo, 2008).

Sumber bakteri dapat berasal dari petugas kesehatan yang tidak steril atau karena teknik operatif kurang tepat(Roy, 2014). Apabila penjahitan luka operasi kurang kuat, maka penutupan luka tersebut akan menjadi terhambat karena sejatinya ujung jaringan pada luka operasi disatukan agar terjadi penyembuhan luka secara primer(Kumar, Abbas \& Aster, 2013). Apabila pertemuan jahitan tersebut longgar, maka dapat terjadi perlambatan pada penyatuan luka. Jaringan luka superfisial yang sedikit terbuka tersebut, dapat terisi oleh bakteri, baik bakteri komensal maupun bakteri nosokomial. Penjahitan luka yang kurang kuat pada pasien dengan berat badan berlebih, dapat menyebabkan luka tersebut tertarik dan sedikit terbuka. Kontak antara lipatan perut dengan luka pasien dapat mentransmisikan bakteri komensal pada kulit lipatan perut seperti Staphylococcus epidermidis ke luka operasi(Chessa, Ganau and Mazzarello, 2015).

Strain Staphylococcus epidermidis yang berada di rumah sakit dapat memiliki gen yang berbeda dengan strain yang berada di epitel kulit manusia. Hal ini karena lingkungan rumah sakit merupakan linkungan yang selektif terhadap bakteri. Bakteri yang tersebar di rumah sakit atau bakteri nosokomial adalah bakteri yang bertahan 
melawan antibiotik dan antiseptik yang ada di rumah sakit, hal ini lah yang menyebabkan sebagian besar bakteri nosokomial resisten terhadap antibiotik. Spesies Staphylococcus, memiliki sifat fleksibilitas genom serta kemampuan resistensi yang tinggi(Ziebuhr et al., 2006). Bakteri ini juga mampu membuat kolonisasi atau biofilm pada peralatan operasi. sifat - sifat tersebutlah yang membuat spesies Staphyoloocccus, seperti Staphylococcus epidermidis menjadi bakteri yang paling sukses tersebar di lingkungan rumah sakit. Beberapa strain Staphylococcus epidermidis memiliki PIA (Polysaccharide Intracellular Adhesin) dan poly-N-succinyl-glucosamine (PNSG) yang menyebabkan bakteri ini menjadi virulen(Chessa, Ganau and Mazzarello, 2015).

Menurut tabel 4, kejadian infeksi oleh bakteri gram negatif lebih kecil dibandingkan gram positif, dimana didapatkan $40 \%$ pasien terinfeksi bakteri gram negatif. Hasil penelitian ini berbeda dengan penelitian Negi, Pal, Juyal, Sharma \& Sharma, (2015). Bakteri gram negatif seperti Escherichia coli adalah bakteri pada saluran pencernaan yang sering ditemukan pada infeksi luka operasi pasca bedah abdomen(Negi et al., 2015). Bakteri gram negatif ini bisa saja telah tereradiksi oleh antibiotik profilaksis yang digunakan.

\section{SIMPULAN}

Setelah dilakukan penelitian dan pengolahan data, maka dapat diambil kesimpulan sebagai berikut:

1. Kejadian infeksi luka operasi pada pergantian balutan pertama di RSUD Abdul Wahab Sjahranie Samarinda teridentifikasi pada $75 \%$ pasien yang menjadi sampel penelitian.

2. Sebagian besar kejadian infeksi luka operasi terjadi pada pasien dengan usia diatas 40 tahun.

3. Pada $67,5 \%$ pasien terinfeksi tidak didapatkan penyakit penyerta.

4. Bakteri gram positif, yaitu Staphylococcus epidermidis merupakan bakteri terbanyak yang teridentifikasi pada pasien infeksi luka operasi.

5. Seluruh pasien yang mendapatkan infeksi luka operasi menerima antibiotik profilaksis.

6. Sebagian besar kejadian infeksi luka operasi ditemukan pada $42,5 \%$ pasien dengan status gizi normal dan kejadian infeksi luka operasi pada pasien dengan berat badan berlebih dan obesitas lebih tinggi dibandingkan kejadian tidak terinfeksi. 
Jurnal Kebidanan Mutiara Mahakam, Vol 8, No 1, Tahun 2020, Hal 21-37

7. Sebagian besar pasien terinfeksi meupakan pasien dengan jenis luka operasi bersih terkontaminasi dengan durasi operasi $<120$ menit.

\section{DAFTAR PUSTAKA}

Agrawal, A. and Singh, R. P. (2014) 'Surgical Site Infection in Abdominal Surgeries: a Clinical Study', Journal of Evolution of Medical and Dental Sciences, 3(40), pp. 10188-10193. doi: 10.14260/jemds/2014/3324.

Al-Niaimi, A. N. et al. (2015) 'Intensive postoperative glucose control reduces the surgical site infection rates in gynecologic oncology patients', Gynecologic Oncology. Elsevier B.V., 136(1), pp. 71-76. doi: 10.1016/j.ygyno.2014.09.013.

Alkaaki, A. et al. (2019) 'Surgical site infection following abdominal surgery: A prospective cohort study', Canadian Journal of Surgery, 62(2), pp. 111-117. doi: $10.1503 /$ cjs.004818.

Behnke, M. et al. (2013) 'Nosokomiale Infektionen und Antibiotika-Anwendung: Zweite nationale Prävalenzstudie in Deutschland', Deutsches Arzteblatt International, 110(38), pp. 627-633. doi: 10.3238/arztebl.2013.0627.

Beliman, G., \& Dunn, D. (2015). Surgical Infection. Dalam: Brunicardi, C. (ed.). Schwartz's Principles Of Surgery. Edisi ke-10. McGraw Hill Education, New York, pp. $135-160$

Blanchard, D. (2015) 'Prophylactic antibiotics to prevent surgical site infection after breast cancer surgery', Clinical Journal of Oncology Nursing, 19(5), pp. 629-630. doi: 10.1188/15.CJON.629-630.

CDC (2019) 'Procedure-associated Module SSI Surgical', $C d c$, (January), pp. 20-31. doi: 10.1080/17436753.2016.1267942.

Chessa, D., Ganau, G. and Mazzarello, V. (2015) 'An overview of staphylococcus epidermidis and staphylococcus aureus with a focus on developing countries', Journal of Infection in Developing Countries, 9(6), pp. 547-550. doi: 10.3855/jidc.6923.

Cogen, A. L., Nizet, V. and Gallo, R. L. (2008) 'FROM BENCH TO BEDSIDE Skin microbiota : a source of disease or defence?', British Journal of Dermatology, 158, pp. 442-455.

Collaborative, G. (2017) 'Determining the worldwide epidemiology of surgical site infections after gastrointestinal resection surgery: Protocol for a multicentre, international, prospective cohort study (GlobalSurg 2)', BMJ Open, 7(7), pp. 1-7. doi: 10.1136/bmjopen-2016-012150.

Dobner, J. and Kaser, S. (2018) 'Body mass index and the risk of infection - from underweight to obesity', Clinical Microbiology and Infection. Elsevier Ltd, 24(1), pp. 24-28. doi: 10.1016/j.cmi.2017.02.013. 
Jurnal Kebidanan Mutiara Mahakam, Vol 8, No 1, Tahun 2020, Hal 21-37

Dokken, B. B. (2008) 'The pathophysiology of cardiovascular disease and diabetes: Beyond blood pressure and lipids', Diabetes Spectrum, 21(3), pp. 160-165. doi: 10.2337/diaspect.21.3.160.

Emil, A. et al. (2015) 'Surgical site infections after abdominal surgery: Incidence and risk factors. A prospective cohort study', Infectious Diseases, 47(11), pp. 761-767. doi: $10.3109 / 23744235.2015 .1055587$.

Faridah, I. N., Andayani, T. M. and Inayati, I. (2012) 'Pengaruh Umur Dan Penyakit Penyerta Terhadap Resiko Infeksi Luka Operasi Pada Pasien Bedah Gastrointestinal', Pharmaciana, 2(2). doi: 10.12928/pharmaciana.v2i2.668.

'Global Guidelines for the Prevention of Surgical Site Infection' (2016). Available at: http://www.who.int.

Haryanti, L. et al. (2016) 'Prevalens dan Faktor Risiko Infeksi Luka Operasi Pascabedah', Sari Pediatri, 15(4), p. 207. doi: 10.14238/sp15.4.2013.207-12.

$\mathrm{Hu}$, T. et al. (2018) 'Incidence and risk factors for incisional surgical site infection in patients with Crohn's disease undergoing bowel resection', Gastroenterology Report, 6(3), pp. 189-194. doi: 10.1093/gastro/goy007.

Janugade, H. B. et al. (2016) 'Abdominal Surgical Site Infection Occurrence and Risk Factors in Krishna Institute of Medical', 3(11), pp. 53-56. doi: 10.17354/ijss/2016/56.

Kallstrom, G. (2014) 'Are quantitative bacterial wound cultures useful?', Journal of Clinical Microbiology, 52(8), pp. 2753-2756. doi: 10.1128/JCM.00522-14.

Kiran, R. P. et al. (2015) 'Combined preoperative mechanical bowel preparation with oral antibiotics significantly reduces surgical site infection, anastomotic leak, and ileus after colorectal surgery', Annals of Surgery, 262(3), pp. 416-423. doi: 10.1097/SLA.0000000000001416.

Kumar, V., Abbas, A. K., \& Aster, J. C. (2013).Robbins Basic Pathology.Edisi ke-9. Elsevier.Singapura.

Kunkemoeller, B. and Kyriakides, T. R. (2017) 'Redox Signaling in Diabetic Wound Healing Regulates Extracellular Matrix Deposition', Antioxidants and Redox Signaling, 27(12), pp. 823-838. doi: 10.1089/ars.2017.7263.

Kurnia, A., Tripriadi, E. S. and Andrini, F. (2013) 'Gambaran Penderita Infeksi Luka Operasi pada Pasien Pasca Operasi Bersih ( Clean ) di RSUD Arifin Achmad Provinsi Riau', Journal of Chemical Information and Modeling, 53(9), pp. 16891699. doi: 10.1017/CBO9781107415324.004.

Liu, W. et al. (2014) 'Third-generation cephalosporins as antibiotic prophylaxis in neurosurgery: What's the evidence?', Clinical Neurology and Neurosurgery. Elsevier B.V., 116, pp. 13-19. doi: 10.1016/j.clineuro.2013.10.015.

Montecino-rodriguez, E. et al. (2013) 'Causes, consequences, and reversal of immune 
system aging Find the latest version: Review series Causes, consequences, and reversal of immune system aging', The Journal of clinical investigation, 123(3), pp. 958-965. doi: 10.1172/JCI64096.958.

Negi, V. et al. (2015) 'Bacteriological profile of surgical site infections and their antibiogram: A study from resource constrained rural setting of Uttarakhand state, India', Journal of Clinical and Diagnostic Research, 9(10), pp. DC17-DC20. doi: 10.7860/JCDR/2015/15342.6698.

Otto, M. (2009). Staphylococcus epidermidis - the "accidental" pathogen. Nat Rev Microbiol , 7(8), pp. 555-567. https://doi.org//10.1038/nrmicro2182.

Roy, M.-C. (2014) 'A Guide to Infection Control in the Hospital', Infection control \& urological care, 7(1), p. 16. Available at: www.isid.org.

Spagnolo, A. M. et al. (2013) 'Operating theatre quality and prevention of surgical site infections', Journal of Preventive Medicine and Hygiene, 54(3), pp. 131-137.

Steiner, H. L. and Strand, E. A. (2017) 'Surgical-site infection in gynecologic surgery: pathophysiology and prevention', American Journal of Obstetrics and Gynecology. Elsevier Inc., 217(2), pp. 121-128. doi: 10.1016/j.ajog.2017.02.014.

Thelwall, S. et al. (2015) 'Impact of obesity on the risk of wound infection following surgery: Results from a nationwide prospective multicentre cohort study in England', Clinical Microbiology and Infection. Elsevier Ltd, 21(11), p. 1008.e11008.e8. doi: 10.1016/j.cmi.2015.07.003.

Warganegara, E., Apriliana, E. and Ardiansyah, R. (2012) 'Identifikasi Bakteri Penyebab Infeksi Luka Operasi ( ILO ) Nosokomial Pada Ruang Rawat Inap Bedah dan Kebidanan RSAM di Bandar Lampung', Prosiding SNSMAIP III, (978-602-985591-3), pp. 344-348.

Winfield, R. D. et al. (2016) 'Obesity and the risk for surgical site infection in abdominal surgery', American Surgeon, 82(4), pp. 331-336.

Xia, J., Gao, J. and Tang, W. (2016) 'Nosocomial infection and its molecular mechanisms of antibiotic resistance', BioScience Trends, 10(1), pp. 14-21. doi: 10.5582/bst.2016.01020.

Ziebuhr, W. et al. (2006) 'Nosocomial infections by Staphylococcus epidermidis: how a commensal bacterium turns into a pathogen', International Journal of Antimicrobial Agents, 28(SUPPL. 1), pp. 14-20. doi: 10.1016/j.ijantimicag.2006.05.012. 